\title{
Persorption of Luminal Antigenic Molecule and Its Specific Antibody via Apoptotic Epithelial Cells of Intestinal Villi and Peyer's Patches into Peripheral Blood in Rats
}

\author{
Midori YUJI ${ }^{1)}$, Masahito TSUBATA ${ }^{2)}$, Keigi CHIN ${ }^{1)}$, Sachiko ONISHI ${ }^{1)}$, Tetsurou INAMOTO ${ }^{1)}$, Wang-Mei QI ${ }^{1}$, \\ Katsuhiko WARITA ${ }^{1)}$, Toshifumi YOKOYAMA ${ }^{3)}$, Nobuhiko HOSHI ${ }^{1)}$ and Hiroshi KITAGAWA ${ }^{1) *}$ \\ ${ }^{1)}$ Departments of Bioresource and Agrobiosciences and ${ }^{2)}$ Animal Science, Graduate School of Science and Technology, Kobe University, \\ Kobe 657-8501 and ${ }^{3)}$ Department of Anatomy and Neurobiology, Faculty of Medicine, Kagawa University, Kagawa 761-0793, Japan
}

(Received 3 April 2006/Accepted 29 August 2006)

ABSTRACT. The possibility of persorption of bovine serum albumin (BSA) molecules from mucous epithelial cells and its mechanism were investigated in rats orally pre-immunized by BSA for 14 consecutive days. In the small and large intestines, both the BSA antigen (BSA$\mathrm{Ag}$ ) and its specific antibody (SpAb) were absorbed by the epithelial cells at the late apoptotic stage (ApoEp), and were subsequently transcytosed by membranes of the small vesicles. The basal cytoplasms containing highly-concentrated BSA-Ag and SpAb were occasionally fragmented into small cytoplasmic droplets that were secreted into the lamina propria. In Peyer's patches, both BSA-Ag and $\mathrm{SpAb}$ were more actively absorbed and transcytosed toward the dome area by the ApoEp of the dome apex than by the M cells. BSA-Ag and SpAb were finally persorbed into the portal blood and lymph, but were never secreted into the bile. They were also engulfed by macrophage-like cells in the villous lamina propria, mesenteric lymph node and spleen, and by hepatocytes in the liver. These findings suggest that sensitized soluble luminal antigens are taken up by ApoEp in the small intestine and are finally persorbed into the peripheral blood. The uptake of luminal antigen might be mediated by its luminal SpAb.

KEY WORDS: antigen, apoptosis, epithelial cell, persorption, specific antibody.

J. Vet. Med. Sci. 68(12): 1297-1305, 2006

It is generally believed that ingested foods are digested in the alimentary canal into low-molecular nutrients such as amino acids, small peptides, mono saccharides, fatty acids and glycerol. These low-molecular nutrients are mainly absorbed by the villous columnar epithelial cells in the small intestine. The absorption of macromolecules is almost entirely restricted by ordinary intestinal epithelial cells in adult animals [2]. However, there is now indisputable evidence that small amounts of intact peptides and proteins do enter the blood circulation under normal physiological conditions [8]. Moreover, orally-ingested intact macromolecules such as ovalbumin and several particulates such as diatomes, pollens, spores, cellulose particles, plant cells, starch granules, polyvinyl chloride particles or metallic particles $[8,14,15,19,45,46]$, are transported into the systemic circulation from the intestinal lumen. However, the mechanisms of the persorption have not yet been clarified.

Orally-administrated antigens induce the immune responses in alimentary tracts via $\mathrm{M}$ cells of gut-associated lymphoid tissues (GALT) [9]. The intestinal immune responses spread over all mucous membranes throughout the body to build up the so-called common mucosal immune system $[1,10]$. As a result, secretory IgA neutralizes biologically active antigens such as viruses, toxins and enzymes, and prevents both the adherence of bacteria to mucosal surfaces and the invasion of the luminal antigenic molecules into the intestinal tissue [29]. In contrast, oral immunological tolerance is induced in the tissues throughout

\footnotetext{
* Correspondence to: Kitagawa, H., Graduate School of Science and Technology, Kobe University, Kobe 657-8501, Japan.
}

the body except for the mucosa by oral administration of some antigenic materials [7, 23]. Several hypothetic mechanisms on the induction of oral immunological tolerance have been proposed [5]. That is, the oral administration of low doses of antigen favors the generation of regulatory cell-driven tolerance, whereas that of high doses of antigen favors the anergy-driven tolerance [6, 34]. However, it is still unclear how the luminal food-antigenic information is usually brought to the systemic lymphoid tissues maintaining the oral immunological tolerance throughout the body.

$M$ cells are predominantly located at an undesirable anatomical site, the basal to middle region of the follicleassociated epithelium (FAE) $[21,25,35,40]$. The basal to middle region of the FAE does not directly face the central lumen of the intestinal canal, and thus the $M$ cells are prevented from being in contact with the luminal food antigens by thick mucus. Therefore, it might be difficult for antigenic macromolecules or particulates to diffuse into the mucus towards $\mathrm{M}$ cells under these physiological conditions.

In this study, a new pathway of luminal antigenic macromolecules except for classical pathway, $M$ cells, was immunohistochemically investigated throughout rat intestines.

\section{MATERIALS AND METHODS}

Animals: A total of 10 male Wistar rats aged 5 weeks (Japan SLC Inc., Japan) were maintained under conventional laboratory housing conditions. They were separated into an experimental group $(n=5)$ with oral administration of bovine serum albumin (BSA) and a control 
group ( $n=5)$ with no oral administration of BSA. The animals were treated according to the guidelines for the care and use of experimental animals at Rokkodai Campus of Kobe University. They were permitted free access to water and food (Lab MR Stock; Nosan Corp., Japan) containing no bovine-derived proteins. The animal facility was maintained under conventional conditions with a $12 \mathrm{hr}$ light/dark cycle at $21 \pm 1^{\circ} \mathrm{C}$ and $50-60 \%$ humidity.

Oral immunization: Five animals were drunk $0.75 \%$ BSA (Fraction V; Serologicals Proteins, U.S.A.) solution $(1 \mathrm{~m} l)$ for 14 consecutive days.

Tissue preparation: At $1 \mathrm{hr}$ after the final oral administration of BSA, all animals were intracardially perfused with periodate-lysine-paraformaldehyde fixative (PLP) under anesthesia with inhalation of ethyl ether. Small tissue blocks from the duodenum, jejunum, ileum including Peyer's patch, cecum, colon, rectum, spleen, liver and mesenteric lymph node were obtained and immersion-fixed in the same cold fixative for $24 \mathrm{hr}$ at $4^{\circ} \mathrm{C}$. The tissue blocks were then rapidly dehydrated, embedded in paraffin by routine procedures and cut into $4 \mu \mathrm{m}$ thick sections. They were mounted onto 3-aminopropyltriethoxysilane (ShinEtsu Chemical, Japan) coated glass slides and stored at $4^{\circ} \mathrm{C}$ until use.

Detection of anti BSA antibody: After deparaffinization, endogenous peroxidase was blocked by immersing the sections in absolute methanol and in $0.5 \% \mathrm{H}_{2} \mathrm{O}_{2}$ for $30 \mathrm{~min}$ each followed by incubation with $2 \%$ normal chicken serum for $1 \mathrm{hr}$ at r.t. Thereafter, the sections were treated with $0.01 \%$ dinitrophenyl-BSA (Molecular Probes, U.S.A.) for 1 $\mathrm{hr}$ at r.t. Following incubation with HRP-conjugated anti dinitrophenyl rabbit IgG (diluted at 1:50; Dako, Denmark) for $20 \mathrm{hr}$ at $4^{\circ} \mathrm{C}$, the sections were incubated with 3,3'diaminobenzidine (Dojindo Lab., Japan) solution containing $0.03 \% \mathrm{H}_{2} \mathrm{O}_{2}$ (DAB) and were counterstained with hematoxylin.

Detection of BSA antigen: After removal of the endogenous peroxidase activity, the deparaffinized sections were treated with $1 \%$ normal rabbit serum for $1 \mathrm{hr}$ at r.t. The sections were then incubated with HRP-conjugated anti BSA chicken IgG (diluted at 1:10; ICN Biomedicals, U.S.A.) for $20 \mathrm{hr}$ at $4^{\circ} \mathrm{C}$. Following incubation with DAB, the sections were counterstained with hematoxylin.

Detection of immunoglobulin (Ig) classes: After removal of endogenous peroxidase activity, the deparaffinized sections were treated with $1 \%$ normal rabbit serum for $1 \mathrm{hr}$ at r.t. The sections were then incubated with anti rat $\operatorname{IgA}$ goat IgG (diluted at 1:400; Seikagaku Corp., Japan), anti rat IgG goat IgG (diluted at 1:400; Jackson ImmunoRes. Lab., U.S.A.), or anti rat IgM goat IgG (diluted at 1:200; Jackson ImmunoRes. Lab.) for $20 \mathrm{hr}$ at $4^{\circ} \mathrm{C}$. Following incubation with anti goat IgG rabbit IgG (diluted at 1:400; Jackson ImmunoRes. Lab.) for $1 \mathrm{hr}$ at r.t., the sections were treated with goat peroxidase anti peroxidase complex (PAP) (diluted at 1:400; Jackson ImmunoRes. Lab.) for $1 \mathrm{hr}$ at r.t. Finally, the sections were incubated with DAB and counterstained with hematoxylin.
In situ nick-end labeling method: The bromodeoxyuridin triphosphate (BrdUTP) method was applied to detect the final features of the apoptotic villous columnar epithelial cells according to a method described by $\mathrm{Li}$ and Darzynkiewicz [26]. Briefly, four sections were prepared (Sections 1, 2, 3, and 4). Sections 1 and 2 were used as positive controls for section 3 . Section 4 was used as a negative control. After deparaffinization, the sections were pretreated with $6.0 \mu \mathrm{g} / \mathrm{m} l$ proteinase K solution (SigmaAldrich, U.S.A.) for $15 \mathrm{~min}$ at $37^{\circ} \mathrm{C}$. After treatment with both absolute methanol and $0.5 \% \mathrm{H}_{2} \mathrm{O}_{2}$, sections 1 and 2 were incubated with $1.5 \mathrm{mg} / \mathrm{m} l$ DNase I solution (Boehringer Mannheim, Germany) for $10 \mathrm{~min}$ at $37^{\circ} \mathrm{C}$. Sections 1 and 3 were incubated with terminal deoxynucleotidyl transferase (TdT) buffer (Roche Diagnostics, Switzerland) containing BrdUTP solution (0.1 $\mathrm{nM}$ BrdUTP in $4 \mathrm{ml}$ distilled water; Sigma-Aldrich) for $2 \mathrm{hr}$ at $37^{\circ} \mathrm{C}$. All sections were then incubated with $1 \%$ normal bovine serum for $1 \mathrm{hr}$ at r.t., and were treated with anti BrdUTP mouse monoclonal antibody (diluted at 1:20; Bioscience Products, Japan) for $18 \mathrm{hr}$ at $4^{\circ} \mathrm{C}$. The sections were then reacted with anti mouse $\operatorname{IgG}$ rat $\operatorname{IgG}$ (diluted at 1:50; Jackson ImmunoRes. Lab.) for $1 \mathrm{hr}$ at r.t., and treated with mouse PAP (diluted at 1:50; Seikagaku Corp.) for $1 \mathrm{hr}$ at r.t. Finally, the sections were incubated with DAB and counterstained with hematoxylin.

\section{RESULTS}

BSA-antigen (BSA-Ag) and its specific antibody (SpAb) in intestinal lumen: At $1 \mathrm{hr}$ after the final BSA-administration, BSA-Ag and SpAb were more strongly detected in the chyme than in the mucous layer on the intestinal villi in the small intestine. BSA-Ag and SpAb also diffused into the mucus of the intervillous spaces. In the large intestine, both BSA-Ag and SpAb were faintly detected in the chyme and mucous layer.

$B S A-A g$ and SpAb in the intestinal epithelium: Throughout the small intestine, both BSA-Ag and SpAb were constantly detected in almost all villous columnar epithelial cells at the late apoptotic stage (ApoEp) in the apices of the intestinal villi (Fig. 1). The nuclear DNA was highly fragmented in the ApoEp which contained a high concentration of BSA-Ag and SpAb (Fig. 2). The epithelial cytoplasms were BSA-Ag- and SpAb-positive with various intensities and contained small vesicles having immunopositive membrane with various sizes in the apices of the villi (Fig. 1). In the ApoEp, BSA-Ag and SpAb were also detected in the striated borders in addition to the basal and lateral cell membranes. In addition to the apical regions, $\mathrm{Ag}$ and $\mathrm{SpAb}$ were occasionally detected in the middle regions of the intestinal villi (Fig. 3). In some cases, the basal cytoplasms were fragmented into small cytoplasmic droplets, which contained highly concentrated BSA-Ag and $\mathrm{SpAb}$ (Fig. 4). All Ig classes in the epithelial cells were detected in a similar pattern in both the BSA-Ag and SpAb. The detection intensity of $\operatorname{IgG}$ was stronger than that of $\operatorname{IgA}$, 

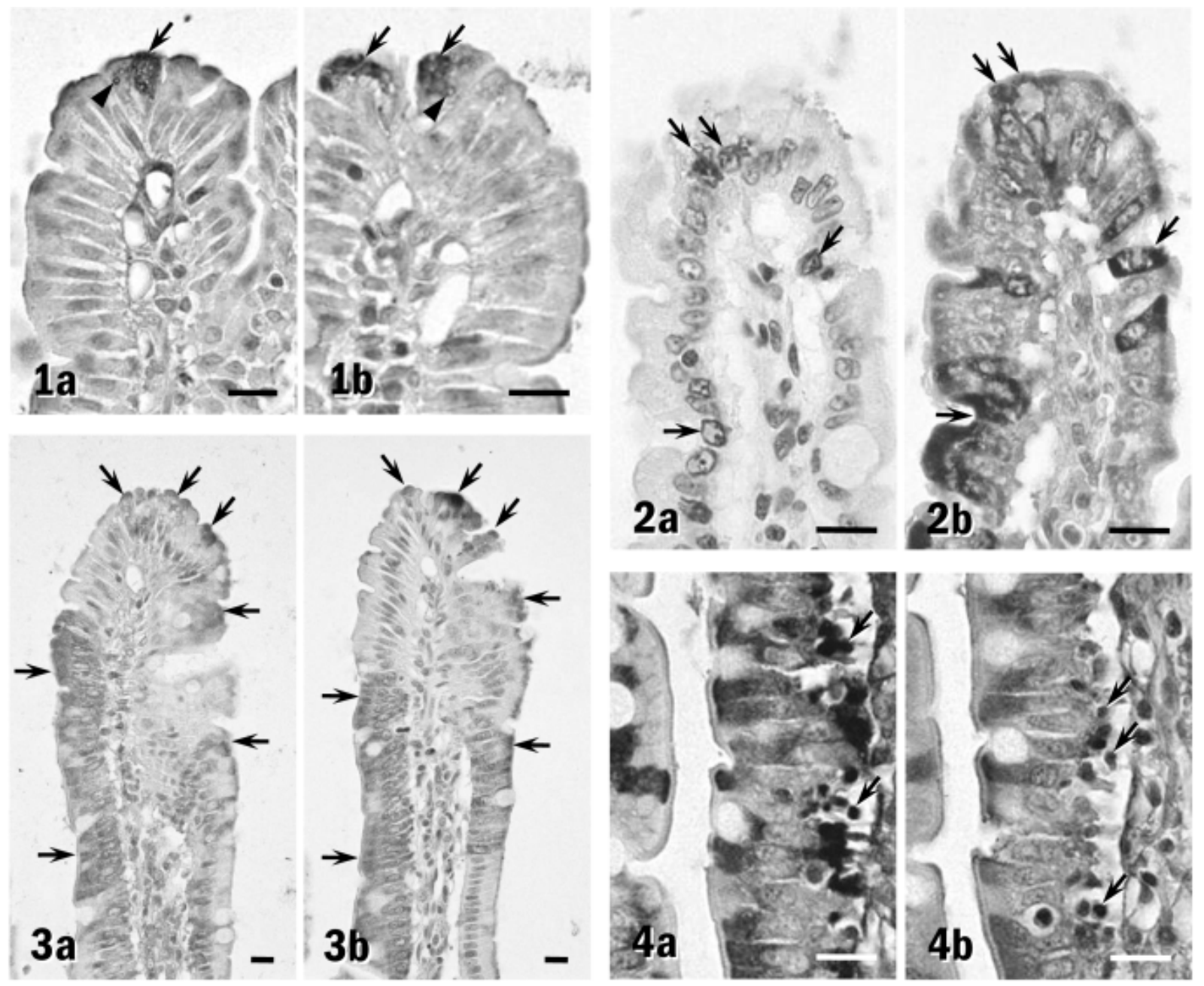

Fig. 1. The epithelial cells were immunopositive to BSA-Ag- (a) and SpAb (b) in the villous apices with various degree of intensity. Strong immunopositivities are seen (arrows). Both positive reactions are visible on the membranes of the small vesicles (arrowheads) in their cytoplasms. Bar $=10 \mu \mathrm{m}$

Fig. 2. In two serial sections, strong DNA-fragmentation (arrows in a) and strongly immunopositive SpAb (arrows in b) are visible in the same epithelial cells of the apex of the intestinal villus. The cytoplasms of other epithelial cells were also partially immunopositive with various degree of intensity (b). Bar $=10 \mu \mathrm{m}$.

Fig. 3. In two sections on different longitudinal planes in the same intestinal villus, BSA-Ag (arrows in a) and its SpAb (arrows in b) are visible in similar portions of the apical half of the villus. Bar $=10 \mu \mathrm{m}$.

Fig. 4. In BSA-Ag- (a) and SpAb-positive (b) epithelial cells, the strongly immunopositive basal cytoplasms are fragmented into small droplets (arrows). The released cytoplasmic droplets also contain the strongly immunopositive BSA-Ag and its SpAb. Bar=10 $\mu \mathrm{m}$.

and that of IgM was weakest (Fig. 5). The detection intensities against BSA-Ag and $\mathrm{SpAb}$ were weaker in the epithelial cells of the jejunum and ileum than in those of the duodenum. In the colon and rectum, BSA-Ag, SpAb and IgG were faintly detected in the most luminal epithelial cells which were in contact with the intestinal lumen, but the detection intensities of IgA and IgM were weaker than IgG. BSA-Ag and SpAb bearing epithelial cells were seldom accompanied by intraepithelial migrating cells in the intestinal villi.

In Peyer's patches, the FAEs were covered by the adjacent follicle-associated intestinal villi, except for the narrow apices. Moreover, the narrow spaces between FAE and the follicle-associated intestinal villi were filled with mucus. Both BSA-Ag and $\mathrm{SpAb}$ were strongly detected in the microvillous columnar epithelial cells of the apical regions of FAEs, but the weakly positive reaction products were located in both the M cells and their pockets in the basal to middle regions of the FAEs. In the positive epithelial cells, BSA-Ag and SpAb were found on the membranes of cytoplasmic vesicles. IgG and $\operatorname{IgA}$ were also detected in FAE in the same manner as the BSA-Ag and SpAb (Fig. 6).

In the control group, the result was similar with that in the experimental group except for no detection of BSA-Ag and 


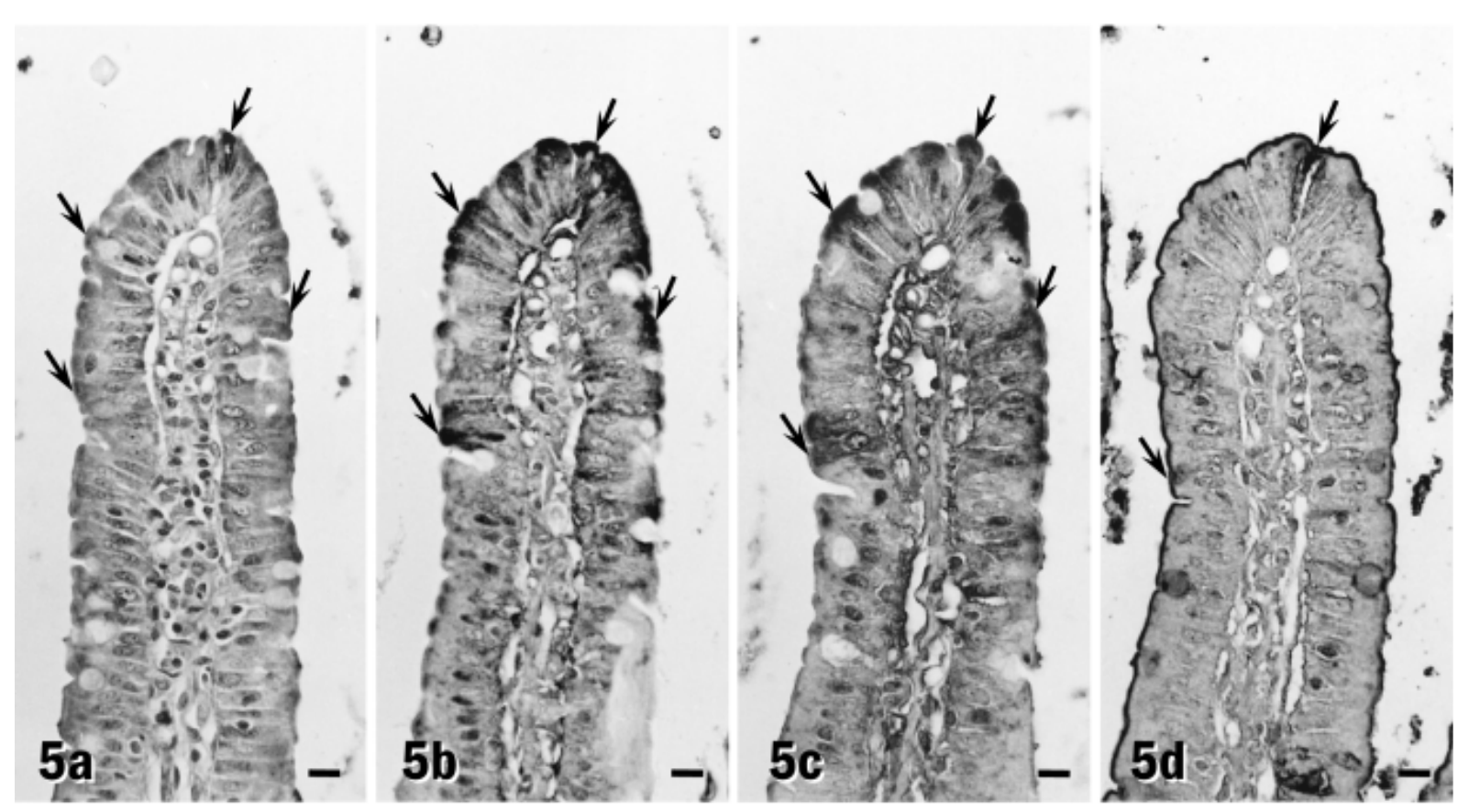

Fig. 5. In four sections on different longitudinal planes in the same intestinal villus, the strong immunopositivity to SpAb is seen in the apical region of the intestinal villus (arrows in a). IgG (arrows in b), IgA (arrows in c) and IgM (arrows in d) are also visible in most of the same portions where the $\mathrm{SpAb}$ is seen. Bar $=10 \mu \mathrm{m}$.
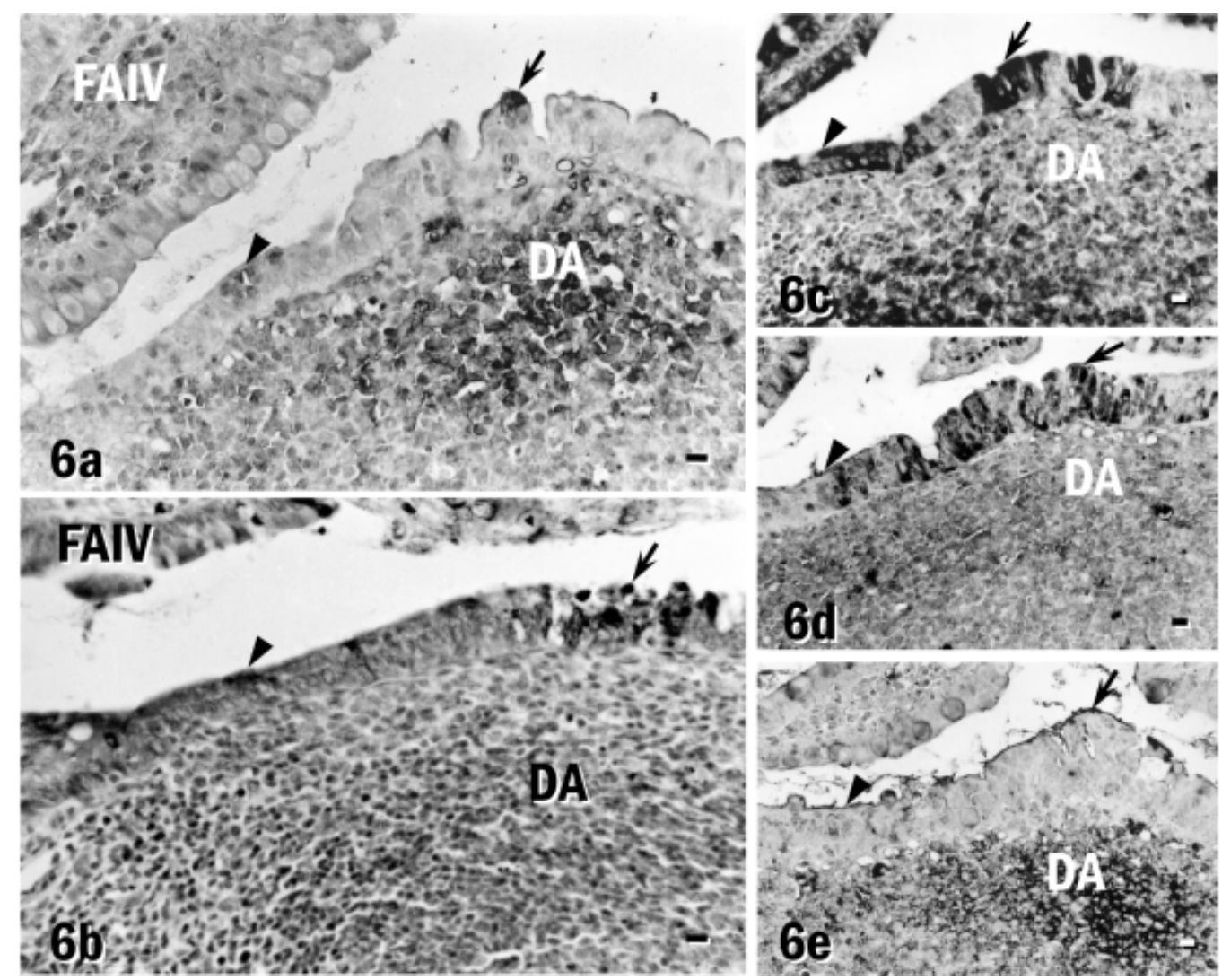

Fig. 6. The BSA-Ag is more strongly detected in the ordinary columnar epithelial cells of the apices (arrow in a) than in $\mathrm{M}$ cells of the basal to middle region (arrowhead in a) in FAE. SpAb (b), $\operatorname{IgG}(\mathrm{c})$ and $\operatorname{IgA}(\mathrm{d})$ are distributed in a similar manner as BSA-Ag (a), except for IgM (e). DA, dome area; FAIV, follicle-associated intestinal villus. Bar=10 $\mu \mathrm{m}$. 

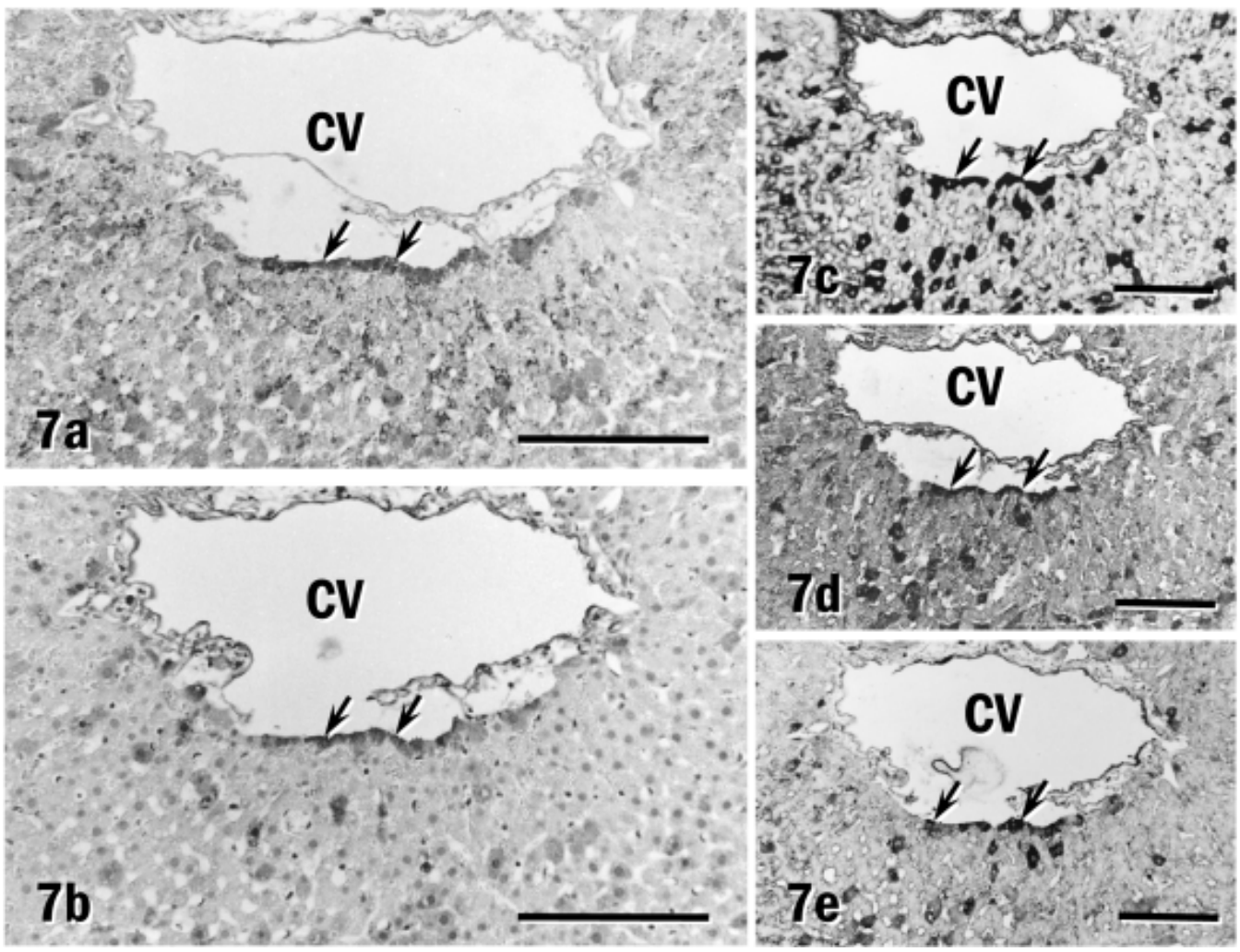

Fig. 7. In the liver, BSA-Ag (a), SpAb (b), IgG (c), IgA (d) and IgM (e) are contained in the hepatocytes. The immunopositive hepatocytes are distributed diffusely in the parenchyma, but accumulate around the central vein (CV) (arrows). Bar=100 $\mu \mathrm{m}$.

$\mathrm{SpAb}$ in all tissues.

Fate of BSA-Ag and SpAb after absorption: Fragmented cytoplasms with the BSA-Ag and SpAb were occasionally found in the blood capillaries and lymph vessels of the lamina propria in the small intestines. BSA-Ag, SpAb and IgG were also found in cytoplasmic granules of the macrophage-like cells in the lamina propria of the intestinal villi.

BSA-Ag, SpAb and all immunoglobulin classes were located in the centrolobular hepatocytes of the liver (Fig. 7). A few stellate macrophages also contained BSA-Ag and $\mathrm{SpAb}$ in their cytoplasmic granules, and all immunoglobulin classes were also detected in the cytoplasmic granules. Additionally, BSA-Ag and SpAb were faintly detected in the epithelium of the interlobular bile duct, but never contained in the bile.

In the spleen, the BSA-Ag- and SpAb-laden macrophagelike cells were sparsely distributed in the marginal zone, red pulp and germinal center (Fig. 8). SpAb was also detected in the cytoplasms and on the cell membranes of the lymphocytes and plasma cells.

In the mesenteric lymph nodes, both BSA-Ag and $\mathrm{SpAb}$ were found in the endothelia and macrophage-like cells in the lymphatic sinuses (Fig. 9). The BSA-Ag- and SpAbladen macrophage-like cells and SpAb-positive plasma cells and lymphocytes were also distributed in the medullary cord and paracortex. In the paracortex, both BSA-Ag and $\mathrm{SpAb}$ were weakly detected in the interstitial cells.

\section{DISCUSSION}

Epithelial apoptosis and absorption of antigen and its specific antibody: The villous columnar epithelial cells which are produced in the intestinal crypts accelerate the apoptotic process in their migration processes and finally exfoliate from the apices of the intestinal villi $[12,41,43$, 44]. In the rat small intestine, DNase I-specific mRNA, which induces the nuclear DNA-fragmentation in villous columnar epithelial cells, appears at the lower third of the intestinal villi [48]. Then, DNase I gradually increases in the epithelial cells along the villous axis in the rat intestinal villi [36]. Therefore, there is no doubt that ApoEp exclusively accumulates in the apices of the intestinal villi. In this study, the absorption of luminal BSA-Ag and SpAb was restricted in the villous apices that fronted the BSA-Ag-containing chyme, and that the apoptotic process was also accelerated. Moreover, the epithelial cells with more active absorption of the BSA-Ag and SpAb were also accompanied by stronger nuclear DNA fragmentation. These findings suggest the close relationship between the epithelial apoptosis and the 


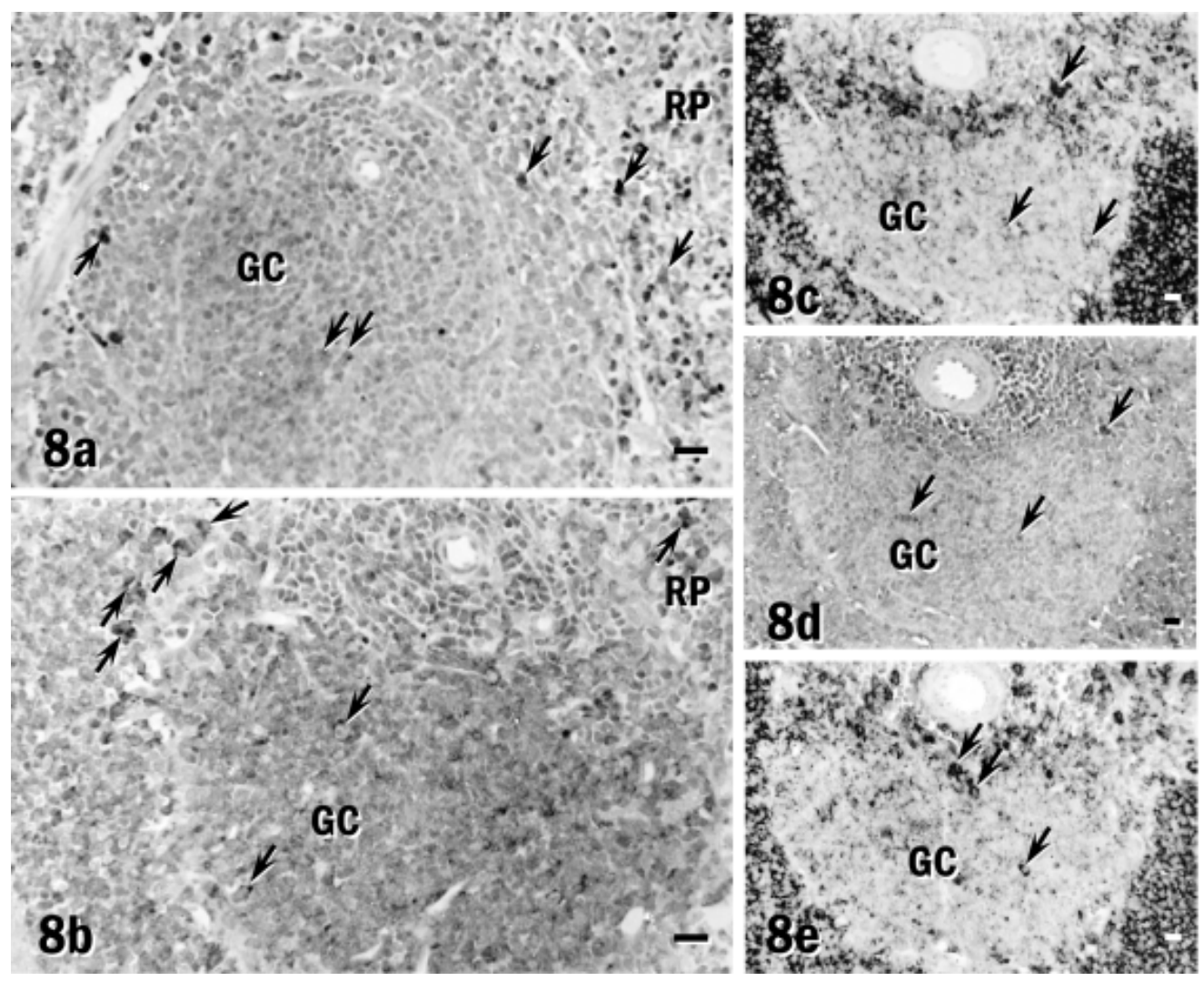

Fig. 8. In the spleen, BSA-Ag- (arrows in a), SpAb- (arrows in b), IgG- (arrows in c), IgA- (arrows in d) and IgM- (arrows in e) laden macrophage-like cells are sparsely distributed in the germinal centers (GC) and red pulp (RP). Bar $=10 \mu \mathrm{m}$.

absorption of both luminal BSA-Ag and SpAb.

The $\mathrm{M}$ cells in FAE absorb luminal antigens to induce intestinal immune responses [9]. M cells are predominantly distributed in the basal to middle region rather than the apical region of the FAE in Peyer's patches of rabbit, human and mouse $[21,35,40]$, the rabbit cecal lymphoid patches [20, 21], and the chicken cecal tonsils [25]. Thus, most $\mathrm{M}$ cells are anatomically located away from the stream of luminal contents. In the present study, both the sensitized BSA-Ag and $\mathrm{SpAb}$ were absorbed by ApoEp rather than by the M cells in Peyer's patches. On the other hand, the lamina proprial dendritic cells in intestinal villi engulf and transport the fragments of ApoEp to the T-cell areas of the mesenteric lymph nodes in rats. This phenomenon is considered to be one of the mechanisms by which oral immunological tolerance is induced and maintained [16]. Consequently, information about the sensitized antigens might be monitored by a special route, ApoEp, in both the intestinal villi and FAE of Peyer's patches, to maintain oral immunological tolerance.

Recently, intestinal villous $M$ cells, which are special $M$ cells, have been reported in mice [18]. Villous $M$ cells which were accompanied by pockets were detected in the epithelium of the intestinal villi by lectin histochemistry by means of UEA-1. In addition, the villous $M$ cells take up three types of bacteria, Salmonella typhimurium, Yersinia pseudotuberculosis and Escherichia coli-expressing invasion [18]. In the present study, however, the BSA-Ag and $\mathrm{SpAb}$-laden epithelial cells were effete microvillous columnar epithelial cells with highly fragmented nuclear DNA which had no pockets. These findings show that the epithelial cells which take up the luminal antigen and antibody are composed of ApoEp itself, unlike intestinal villous $M$ cells in rat intestinal villi.

Absorption mechanism of luminal antigen and its specific antibody: In many mammalian infants, intestinal epithelial cells absorb and transport molecules such as IgG from the maternal colostrum into the systemic blood circulation [13, $22,27,33]$. The absorption of $\operatorname{IgG}$ via enterocytes ceases after weaning [28, 31, 32]. In adult humans, the food antigen and its immune complex are absorbed and transported into the peripheral blood $[8,17]$.

The $\mathrm{IgG}$ is transported by endocytosis mediated by receptors on the epithelial cells in young rats [37]. The mRNA of the neonatal IgG-binding receptor (FcRn) gradually decreases until adulthood in rats [11]. FcRn is, however, expressed on intestinal epithelial cells in adult humans and mediates the transportation of $\operatorname{IgG}$ [4]. Williams and Hemmings [47] found the absorption of IgG and ferritin from enterocytes in adult rats. We showed that 


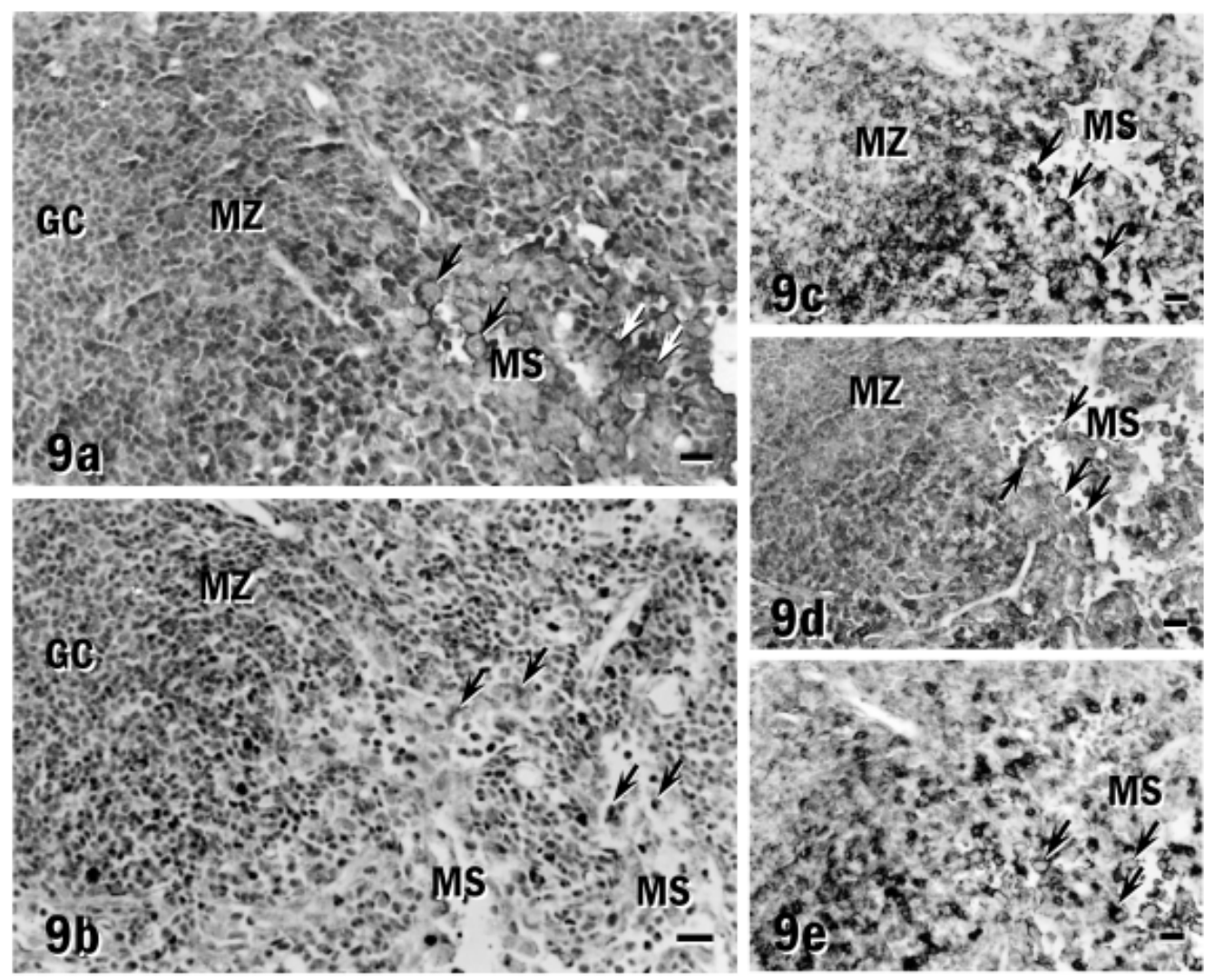

Fig. 9. In the mesenteric lymph node, BSA-Ag (a), SpAb- (b), IgG- (c), IgA- (d) and IgM- (e) laden macrophage-like cells (arrows) are visible in the lymphatic sinus. GC, germinal center; MS, medullary sinus; $\mathrm{MZ}$, mantle zone. Bar $=10 \mu \mathrm{m}$.

BSA-Ag and SpAb were clearly detected on the membranes of the apical cell surfaces and vesicles in ApoEp. This finding suggests the absorption and transcytosis of luminal antigens and specific antibodies are mediated by a membrane receptor, such as FcRn, in ApoEp.

After IgG binds to receptors on the apical membrane, the immunoglobulin is engulfed into the cytoplasm by endocytosis and is released at the basal cell membrane into extracellular spaces under a pH 7.4 milieu [37]. However, ApoEp has strong immunoreactivity for BSA-Ag and SpAb in their basal cytoplasms, and these immunoreactive cytoplasms were separated and released into the lamina propria in this study. This fragmentation, which morphologically resembles apocrine secretion, might be a new route of transporting antigen-antibody complexes to the host tissue.

Fate of absorbed antigen and its specific antibody: Liver possesses a clearance function of various substances from the hepatic portal vein. In humans and other animals, the i.v. injected $\operatorname{IgA}$ is also taken up and catabolized by hepatocytes rather than by nonparenchymal cells in the liver [30]. Egg lecithin-coated silicon particles injected into the portal vein are more actively phagocytosed by hepatocytes than by stellate macrophages in rats $[24,42]$. In the present study,
BSA-Ag and SpAb were predominantly taken up by hepatocytes. From these findings, it was confirmed that the intestine-derived antigens and their specific antibodies were engulfed and processed by hepatocytes rather than by stellate macrophages.

The dimeric IgA is taken up into smooth vesicles of the hepatocytes, transported to the bile canaliculus, and finally secreted into the bile in rats [3]. The intravascular antigenantibody complex is taken up in the liver and is secreted into bile, but not into saliva, urine, milk, or bronchial and intestinal secretions in mice [39]. A double intravenous injection of both dinitrophenyl-human serum albumin (DNP-HSA) and the anti dinitrophenyl antibody of IgA enhances the hepatobiliary transportation of DNP-HSA in mice [38]. Serum IgA transports a large amount of antigen into the bile, but IgG transports only a small amount of low molecular fragments of antigen and IgM, although never in mice [38]. In the present study, neither BSA-Ag nor SpAb derived from intestine were immunohistochemically detected in the bile. Moreover, the positive intensity of the immnoreaction against IgG was stronger than the other Ig classes in ApoEp. These findings suggest that the complexes of food-antigens and specific antibodies derived from intestinal lumen are catabolized in the liver. 
It has been well known that in the phenomenon of persorption, orally-administrated particulates such as starch particles and polyvinyl chloride particles appear in the systemic blood circulation of humans and other mammals $[14,15,46]$. The mechanism by which the specific antibody mediates the persorption of antigenic molecules might be applied to the persorption of particulates from the intestinal lumen to peripheral blood.

ACKNOWLEDGMENTS. This work was financially supported in part by Grants-in-Aid for Scientific Research (nos. 13660298 and 16580239) from the Japan Society for the Promotion of Science.

\section{REFERENCES}

1. Bienenstock, J., McDermott, M. and Befus, D. 1979. A common mucosal immune system. pp. 91-104. In: Immunol. Breast Milk (Ogra, P. L. and Dayton, D. eds.), Raven Press, New York.

2. Bjarnason, I., MacPherson, A. and Hollander, D. 1995. Intestinal permeability: An overview. Gastroenterology 108: $1566-1581$.

3. Daniels, C. K., Schmucker, D. L. and Jones, A. L. 1989. Hepatic asialoglycoprotein receptor-mediated binding of human polymeric immunoglobulin A. Hepatology 9: 229-234.

4. Dickinson, B. L., Badizadegan, K., Wu, Z., Ahouse, J. C., Zhu, X., Simister, N. E., Blumberg, R. S. and Lencer, W. I. 1999. Bidirectional FcRn-dependent IgG transport in a polarized human intestinal epithelial cell line. J. Clin. Invest. 104: 903911.

5. Faria, A. M. C. and Weiner, H. L. 2005. Oral tolerance. Immunological Reviews 206: 232-259.

6. Friedman, A. and Weiner, H. L. 1994. Induction of anergy or active suppression following oral tolerance is determined by antigen dosage. Proc. Natl. Acad. Sci. U.S.A. 91: 6688-6692.

7. Friedman, A., Al-Sabbagh, A., Santos, L. M. B., FishmanLobel, J., Polanski, M., Das, M. P., Khoury, S. J. and Weiner, H. L. 1994. Oral tolerance: A biologically relevant pathway to generate peripheral tolerance against external and self antigens. Chem. Immunol. 58: 259-290.

8. Gardner, M. L. G. 1988. Gastrointestinal absorption of intact proteins. Ann. Rev. Nutr. 8: 329-360.

9. Gebert, A., Rothkötter, H. J. and Pabst, R. 1996. M cells in Peyer's patches of the intestine. Int. Rev. Cytol. 167: 91-159.

10. Gerdts, V., Mutwiri, G. K., Tikoo, S. K. and Babiuk, L. A. 2006. Mucosal delivery of vaccines in domestic animals. Vet. Res. 37: 487-510.

11. Gill, R. K., Mahmood, S., Sodhi, C. P., Nagpaul, J. P. and Mahmood, A. 1999. IgG binding and expression of its receptor in rat intestine during postnatal development. Indian J. Biochem. Biophys. 36: 252-257.

12. Han, H., Iwanaga, T. and Fujita, T. 1993. Species differences in the process of apoptosis in epithelial cells of the small intestine: An ultrastructural and cytochemical study of luminal cell elements. Arch. Histol. Cytol. 56: 83-90.

13. Harada, E., Hashimoto, Y. and Syuto, B. 1992. Precocious cessation of intestinal macromolecular transport by synthetic trypsin inhibitor in suckling rats. Am. J. Physiol. 263: R9961002.

14. Hillyer, J. F. and Albrecht, R. M. 2001. Gastrointestinal persorption and tissue distribution of differently sized colloidal gold nanoparticles. J. Pharm. Sci. 90: 1927-1936.

15. Hodges, G. M., Carr, E. A., Hazzard, R. A. and Carr, K. E. 1995. Uptake and translocation of microparticles in small intestine. Morphology and quantification of particle distribution. Dig. Dis. Sci. 40: 967-975.

16. Huang, F. P., Platt, N., Wykes, M., Major, J. R., Powell, T. J., Jenkins, C. D. and MacPherson, G. G. 2000. A discrete subpopulation of dendritic cells transports apoptotic intestinal epithelial cells to T cell areas of mesenteric lymph nodes. J. Exp. Med. 191: 435-443.

17. Husby, S., Jensenius, J. C. and Svehag, S. E. 1986. Passage of undegraded dietary antigen into the blood of healthy adults. Further characterization of the kinetics of uptake and the size distribution of the antigen. Scand. J. Immunol. 24: 447-455.

18. Jang, M. H., Kweon, M. N., Iwatani, K., Yamamoto, M., Terahara, K., Sasakawa, C., Suzuki, T., Nochi, T., Yokota, Y., Rennert, P. D., Hiroi, T., Tamagawa, H., Iijima, H., Kunisawa, J., Yuki, Y. and Kiyono, H. 2004. Intestinal villous M cells: an antigen entry site in the mucosal epithelium. Proc. Natl. Acad. Sci. U.S. A. 101: 6110-6115.

19. Jani, P., Halbert, G. W., Langridge, J. and Florence, A. T. 1990. Nanoparticle uptake by the rat gastrointestinal mucosa: Quantitation and particle size dependency. J. Pharm. Pharmacol. 42: 821-826.

20. Jepson, M. A., Clark, M. A., Simmons, N. L. and Hirst, B. H. 1993. Epithelial M cells in the rabbit caecal lymphoid patch display distinctive surface characteristics. Histochemistry 100: 441-447.

21. Jepson, M. A., Simmons, N. L., Hirst, G. L. and Hirst, B. H. 1993. Identification of $M$ cells and their distribution in rabbit intestinal Peyer's patches and appendix. Cell Tissue Res. 273: 127-136.

22. Jones, R. E. 1976. The selective uptake and transmission of proteins to the circulation from the small intestine of the suckling rat. Biochim. Biophys. Acta 451: 151-160.

23. Kagnoff, M. E. 1996. Oral tolerance: Mechanisms and possible role in inflammatory joint diseases. Bailliére's Clin. Rheumatol. 10: 41-54.

24. Kanai, M., Murata, Y., Mabuchi, Y., Kawahashi, N., Tanaka, M., Ogawa, T., Doi, M., Soji, T. and Herbert, D. C. 1996. In vivo uptake of lecithin-coated polystyrene beads by rat hepatocytes and sinusoidal endothelial cells. Anat. Rec. 244: 175-181.

25. Kitagawa, H., Hosokawa, M., Takeuchi, T., Yokoyama, T., Imagawa, T. and Uehara, M. 2003. The cellular differentiation of $\mathrm{M}$ cells from crypt undifferentiated epithelial cells into microvillous epithelial cells in follicle-associated epithelia of chicken cecal tonsils. J. Vet. Med. Sci. 65: 171-178.

26. Li, X. and Darzynkiewicz, Z. 1995. Labeling DNA strand breaks with BrdUTP. Detection of apoptosis and cell proliferation. Cell Prolif. 28: 571-579.

27. Mackenzie, D. D. S. 1972. Selective uptake of immunoglobulins by the proximal intestine of suckling rats. Am. J. Physiol. 223: 1286-1295.

28. Martin, M. G., Wu, S. V. and Walsh, J. H. 1997. Ontogenetic development and distribution of antibody transport and $\mathrm{Fc}$ receptor mRNA expression in rat intestine. Dig. Dis. Sci. 42: 1062-1069.

29. Mestecky, J. and McGhee, J. R. 1987. Immunoglobulin A (IgA): Molecular and cellular interactions involved in IgA biosynthesis and immune response. Adv. Immunol. 40: 153-245.

30. Mestecky, J., Moldoveanu, Z., Tomana, M., Epps, J. M., Thorpe, S. R., Phillips, J. O. and Kulhavy, R. 1989. The role of the liver in catabolism of mouse IgA. Immunol. Invest. 18: 313 
324.

31. Morris, B. and Morris, R. 1974. The absorption of ${ }^{125}$ I-labelled immunoglobulin $\mathrm{G}$ by different regions of the gut in young rats. J. Physiol. 241: 761-770.

32. Morris, B. and Morris, R. 1976. The effect of corticosterone and cortisone on the uptake of polyvinyl pyrrolidone and the transmission of immunoglobulin $\mathrm{G}$ by the small intestine in young rats. J. Physiol. 254: 389-403.

33. Morris, B. and Morris, R. 1977. The digestion and transmission of labelled immunoglobulin $\mathrm{G}$ by enterocytes of the proximal and distal regions of the small intestine of young rats. J. Physiol. 273: 427-442.

34. Mowat, A. M., Strobel, S., Drummond, H. E. and Ferguson, A. 1982. Immunological responses to fed protein antigens in mice. I. Reversal of oral tolerance to ovalbumin by cyclophosphamide. Immunology 45: 105-113.

35. Owen, R. L. and Jones, A. L. 1974. Epithelial cell specialization within human Peyer's patches: An ultrastructural study of intestinal lymphoid follicles. Gastroenterology 66: 189-203.

36. Polzar, B., Zanotti, S., Stephan, H., Rauch, F., Peitsch, M. C., Irmler, M., Tschopp, J. and Mannherz, H. G. 1994. Distribution of deoxyribonuclease I in rat tissues and its correlation to cellular turnover and apoptosis (programmed cell death). Eur. J. Cell Biol. 64: 200-210.

37. Rodewald, R. 1980. Distribution of immunoglobulin G receptors in the small intestine of the young rat. J. Cell Biol. 85: $18-32$.

38. Russel, M. W., Brown, T. A. and Mestecky, J. 1981. Role of serum IgA. Hepatobiliary transport of circulating antigen. $J$. Exp. Med. 153: 968-976.
39. Russel, M. W., Brown, T. A. and Mestecky, J. 1982. Preferential transport of IgA-immune complexes to bile compared with other external secretions. Mol. Immunol. 19: 677-682.

40. Savidge, T. C., Smith, M. W., James, P. S. and Aldred, P. 1991. Salmonella-induced M-cell formation in germ-free mouse Peyer's patch tissue. Am. J. Pathol. 139: 177-184.

41. Shibahara, T., Sato, N., Waguri, S., Iwanaga, T., Nakahara, A., Fukutomi, H. and Uchiyama, Y. 1995. The fate of effete epithelial cells at the villus tips of the human small intestine. Arch. Histol. Cytol. 58: 205-219.

42. Soji, T., Murata, Y., Ohira, A., Nishizono, H., Tanaka, M. and Herbert, D. C. 1992. Evidence that hepatocytes can phagocytize exogenous substances. Anat. Rec. 233: 543-546.

43. Takeuchi, T., Kitagawa, H., Imagawa, T. and Uehara, M. 1998. Proliferation and cellular kinetics of villous epithelial cells and M cells in the chicken caecum. J. Anat. 193: 233-239.

44. Takeuchi, T., Kitagawa, H., Imagawa, T. and Uehara, M. 1999. Apoptosis of villous epithelial cells and follicle-associated epithelial cells in chicken cecum. J. Vet. Med. Sci. 61: 149-154.

45. Volkheimer, G. 1977. Persorption of particles: Physiology and pharmacology. Adv. Pharmacol. Chemother. 14: 163-187.

46. Volkheimer, G. 1993. Persorption von mikropartikeln. Pathologe 14: 247-252.

47. Williams, E. W. and Hemmings, W. A. 1978. Intestinal uptake and transport of proteins in the adult rat. Proc. R. Soc. Lond. B. Biol. Sci. 203: 177-189.

48. Zanotti, S., Polzar, B., Stephan, H., Doll, U., Niessing, J. and Mannherz, H. G. 1995. Localization of deoxyribonuclease I gene transcripts and protein in rat tissues and its correlation with apoptotic cell elimination. Histochemistry 103: 369-377. 